\title{
Phytophthora boodjera sp. nov., a damping-off pathogen in production nurseries and from urban and natural landscapes, with an update on the status of $P$. alticola
}

\author{
Agnes V. Simamora ${ }^{1}$, Mike J. C. Stukely ${ }^{2}$, Giles E. StJ. Hardy ${ }^{1}$, and Treena I. Burgess ${ }^{1}$ \\ corresponding author e-mail: tburgess@murdoch.edu.au \\ ${ }^{2}$ Science Division, Department of Parks and Wildlife, Locked Bag 104, Bentley Delivery Centre, WA 6983, Australia \\ Abstract: A new homothallic Phytophthora species, isolated in Western Australia (WA), is described as \\ Phytophthora boodjera sp. nov. It produces persistent, papillate sporangia, oogonia with thick-walled oospores, \\ and paragynous antheridia. Although morphologically similar to $P$. arenaria, phylogenetic analyses of the \\ ITS, cox1, HSP90, $\beta$-tubulin and enolase gene regions revealed $P$. boodjera as a new species. In addition, \\ $P$. boodjera has a higher optimal temperature for growth and a faster growth rate. Phytophthora boodjera has \\ only recently been found in Western Australia and has mostly been isolated from dead and dying Eucalyptus \\ seedlings in nurseries and from urban tree plantings, and occasionally from disturbed natural ecosystems. It is \\ found in association with declining and dying Agonis flexuosa, Banksia media, B. grandis, Corymbia calophylla, \\ Eucalyptus spp,. and Xanthorrhoea preissii. The status of $P$. alticola was also reviewed. The loss of all isolates \\ associated with the original description except one; discrepancies in both sequence data and morphology of \\ the remaining isolate with that presented the original description, and inconclusive holotype material places the \\ status of this species in doubt.
}

${ }^{1}$ Centre for Phytophthora Science and Management, School of Veterinary and Life Sciences, Murdoch University, Perth, WA, 6150, Australia;

\author{
Key words: \\ Eucalyptus \\ multi-gene phylogeny \\ Oomycota \\ Phytophthora arenaria
}

Article info: Submitted: 16 January 2015; Accepted: 9 September 2015; Published: 6 October 2015.

\section{INTRODUCTION}

Numerous Phytophthora species have been associated with damping-off and seedling diseases in plant production nurseries worldwide (Hardy \& Sivasithamparam 1988, Davison et al. 2006, Warfield et al. 2008, Moralejo et al. 2009, Goss et al. 2011, Lilja et al. 2011, Leonberger et al. 2013, Pérez-Sierra \& Jung 2013, Prospero et al. 2013, Schoebel et al. 2014). Phytophthora species are dispersed via the roots of infected plants, soil from potted plants, growth media and water, and in some cases by aerial transmission. Transfer of plants and plant products by human activity and through globalisation in trading is now generally accepted as the main method of introduction of exotic pathogens and pests. The most high-risk pathway for the movement of Phytophthora is "plants for plantings" (Brasier 2008, Liebhold et al. 2012, Scott et al. 2013). Plants infected at production nurseries can potentially distribute Phytophthora species to parks and reserves, amenity plantings, plantations, rehabilitation and biodiversity plantings, wildflower farms, retail nurseries, and gardens. Many Phytophthora species, such as $P$. nicotianae, $P$. plurivora (often reported as $P$. citricola), $P$. cactorum and $P$. citrophthora, tend to be the most commonly recovered from nurseries worldwide, strongly supporting their dissemination through the nursery trade. Because of the level of attention that has been given to this important topic, it is now rare for a new species to be detected in nurseries (Moralejo et al. 2009). Nevertheless the number of reports of Phytophthora species damaging to nursery trees, forests and natural ecosystems is increasing and this has significant implications for international plant biosecurity and plant health practice (Kroon et al. 2012).

The most significant new detection of the past 20 years is Phytophthora ramorum (Grünwald et al. 2012, Parke \& Grünwald 2012). Phytophthora ramorum was first detected infecting Viburnum and Rhododendron in plant nurseries in Germany and The Netherlands in 1993 (Werres et al. 2001), and has subsequently been found in various nurseries all over Europe and North America. It has been recognized as an alien aggressive species in natural areas of the west coast of the USA where it causes sudden oak death, and in Cornwall in the UK (Rizzo et al. 2002, Brasier et al. 2004). Spread through the international nursery trade, $P$. ramorum poses a serious risk to plant biosecurity worldwide (Brasier 2008, Parke \& Lucas 2008, Parke \& Grünwald 2012).

In recent years, many new Phytophthora species have been described from natural ecosystems in Western Australia (WA) (Burgess et al. 2009, Scott et al. 2009, Rea et al. 2010, Jung et al. 2011a, b, Rea et al. 2011, Aghighi et al. 2012, Burgess et al. 2012, Crous et al. 2012, Hüberli et al. 2013). In 2011, a new damping-off disease was reported in WA nurseries growing Eucalyptus and other species for

๑) 2015 International Mycological Association

You are free to share - to copy, distribute and transmit the work, under the following conditions:

Attribution: $\quad$ You must attribute the work in the manner specified by the author or licensor (but not in any way that suggests that they endorse you or your use of the work).

Non-commercial: $\quad$ You may not use this work for commercial purposes.

No derivative works: You may not alter, transform, or build upon this work.

For any reuse or distribution, you must make clear to others the license terms of this work, which can be found at http://creativecommons.org/licenses/by-nc-nd/3.0/legalcode. Any of the above conditions can be waived if you get permission from the copyright holder. Nothing in this license impairs or restricts the author's moral rights. 
restoration of agricultural land. ITS sequence data of the isolates did not match any known species, but were closely related to $P$. alticola and $P$. arenaria and were an exact match for a single WA isolate designated as " $P$. taxon arenaria-like" by Rea et al. (2011).

Phytophthora arenaria has been isolated primarily from Kwongan vegetation and mainly from Banksia species on the northern sandplains in south-west WA (Rea et al. 2011). Phytophthora alticola was first isolated and described by Maseko et al. 2007 from cold-tolerant Eucalyptus species (E. dunnii, E. bajensis, and E. macarthurii) with collar and root rot in South African plantations at an altitude above 1150 $\mathrm{m}$. The new taxon has been isolated in WA from dead and dying Eucalyptus seedlings in nurseries and from adult plants in the urban landscape, predominantly from eucalypts, and occasionally from Banksia species and Corymbia calophylla in natural ecosystems.

Further investigation of isolates thought to be $P$. arenaria in the Vegetation Health Service (VHS) collection of the WA Department of Parks and Wildlife (Burgess et al. 2009) and other recent collections from urban surveys (Barber et al. 2012) revealed two distinct groups of isolates. The first group were of $P$. arenaria, while the second appeared to be a new species related to $P$. alticola (Maseko et al. 2007). In the current study, the $P$. alticola/ $P$. arenaria species complex was re-evaluated using a combination of morphology and a multigene phylogeny resulting in the recognition of a new species, described here as $P$. boodjera sp. nov., and an investigation into the status of $P$. alticola.

\section{MATERIALS AND METHODS}

\section{Isolates}

The majority of isolates used were obtained from the Vegetation Health Service (VHS) Collection, Department of Parks and Wildlife, Perth, Western Australia. All isolates were baited from soil and root material using Eucalyptus sieberi cotyledons. The isolates were maintained in $90 \mathrm{~mm}$ Petri dishes on V8 agar (V8A, $0.1 \mathrm{~L}$ filtered V8 juice, $17 \mathrm{~g}$ agar, $0.1 \mathrm{~g} \mathrm{CaCO} 3,0.9 \mathrm{~L}$ distilled water) and on $5 \mathrm{~mm}$ V8A discs stored in $20 \mathrm{~mL}$ sterile water in McCartney bottles at room temperature. The ex-type isolates of $P$. alticola were obtained from CBS (CBS-KNAW Fungal Biodiversity Centre, Utrecht). Sequence data from related species were obtained from GenBank (www.ncbi.nlm.nih.gov/genbank) the Phytophthora Database (PD; www.phytophthoradb.org), and q-bank (www.q-bank.eu). When all isolates in the CMW collection (Forestry and Agriculture Biotechnology Institute, University of Pretoria, SA) were evaluated and it was found that all isolates of $P$. alticola except CMW 19425 had perished, that isolate was re-numbered CMW 34279. All isolates used in this study are detailed in Table 1 , and the status of all $P$. alticola isolates is given in Table 2.

\section{DNA isolation, amplification and sequencing}

The Phytophthora isolates were cultured on half-strength potato dextrose agar (PDA) (Becton Dickinson, Sparks, MD), $19.5 \mathrm{~g}$ PDA, $7.5 \mathrm{~g}$ agar and $1 \mathrm{~L}$ of distilled water) at $20{ }^{\circ} \mathrm{C}$ for 2 wk. Mycelium was collected by scraping from the agar surface with a sterile blade and placing in a $1.5 \mathrm{~mL}$ sterile Eppendorf $\circledast$ tube. It was frozen in liquid nitrogen and crushed to a fine powder, and genomic DNA was extracted following the method of Andjic et al. (2007). In all cases, the PCR reaction mixtures were as described previously (Andjic et al. 2007) but using the PCR conditions described in the original papers (cited below). The region spanning the internal transcribed spacer (ITS1-5.8S-ITS2) region of the ribosomal DNA was amplified using the primers DC6 (Cooke et al. 2000) and ITS-4 (White et al. 1990). The mitochondrial gene cox1 was amplified with primers FM77 and FM 84 (Martin \& Tooley 2003). Heat shock protein 90 (HSP) was amplified with HSP90-F int and HSP90-R1 primers (Blair et al. 2008). $\beta$-tubulin (BT) was amplified with primers BTF1A and BTR1, and enolase (ENO) was amplified with primers Enl Fy and Enl R1 according to Kroon et al. (2004).

All gene regions were sequenced in both directions with the primers used in amplification. The clean-up products and sequencing were accomplished as described previously (Sakalidis et al. 2011). All sequences derived in this study were added to GenBank, and the accession numbers are provided in Table 1.

\section{Phylogenetic analysis}

The data set consisted of sequences of Phyophthora boodjera sp. nov., $P$. alticola and $P$. arenaria isolates used in this study, and other closely related species in ITS clade 4 (Table 1) which were compiled and manually edited in Geneious v. R7 (http://www.geneious.com/) and Bayesian analysis conducted using a MrBayes (Ronquist et al. 2012) plugin within Geneious after determining the most appropriate substitution model with jModelTest-2.1.4 (Darriba et al. 2012). Alignment files and trees can be viewed on TreeBASE (http:// www.treebase.org/).

\section{Culture characteristics}

Circular inoculum plugs ( $5 \mathrm{~mm}$ diam) were taken from the margin of $7 \mathrm{~d}$-old cultures on V8A and placed in the centre of $90 \mathrm{~mm}$ Petri dishes of the test media. Morphology of hyphal and colony growth patterns were defined from $7 \mathrm{~d}$-old cultures grown at $20^{\circ} \mathrm{C}$ in the dark on V8A, malt extract agar (MEA), carrot agar (CA; $0.1 \mathrm{~L}$ filtered carrot juice, $17 \mathrm{~g}$ agar and 0.9 $L$ distilled water) and half-strength PDA (all from $B B L$, Becton Dickinson, Sparks, MD). Colony morphology was described according to Erwin \& Ribeiro (1996). For temperature growth studies, all isolates were subcultured onto V8A plates and incubated for $24 \mathrm{~h}$ at $20^{\circ} \mathrm{C}$ for growth stimulation. The plates were then moved to incubators fixed at 4, 10, 15, 20, 25, 30, $32.5,35$ and $37.5^{\circ} \mathrm{C}$. Plates were observed daily to ensure that the colonies did not reach the edge of the Petri dish; the radial growth rate was measured after 4-7 d, along two lines crossing the middle of the inoculum plug at right angles, and the mean growth rates ( $\mathrm{mm}$ per day) were assessed. After $7 \mathrm{~d}$, plates with no colony growth at $35^{\circ} \mathrm{C}$ and $37.5^{\circ} \mathrm{C}$ were returned to $20^{\circ} \mathrm{C}$ for $7 \mathrm{~d}$ to check the isolate viability.

\section{Morphology}

Sporangia were produced by flooding $15 \times 15 \mathrm{~mm}$ square agar discs, removed from the growing edge of 3-5-d-old 
colonies on V8A in $90 \mathrm{~mm}$ Petri dishes, with sterile water at $18-25^{\circ} \mathrm{C}$ with their surfaces submerged, in natural daylight. This water was decanted and replaced twice (after 4 and 6 h). In the final change, $1 \mathrm{~mL}$ of non-sterile soil extract was also added and the Petri dishes were incubated overnight. The soil extract was made by suspending $100 \mathrm{~g}$ of pine (Pinus radiata) bark potting mixture in $1 \mathrm{~L}$ distilled water and incubating this on an orbital shaker for $24 \mathrm{~h}$ at $20{ }^{\circ} \mathrm{C}$ before filtering through Whatman no. 1 paper to remove soil particles. After $18-36 \mathrm{~h}$, dimensions and characteristic features of 50 mature sporangia of each isolate, selected at random, were ascertained at $400 \mathrm{x}$ in a BX51 Olympus microscope.

Gametangia were produced by all isolates on V8A in the dark at $20{ }^{\circ} \mathrm{C}$ after $7 \mathrm{~d}$. After $14 \mathrm{~d}$, dimensions and characteristic features of 50 randomly-selected mature oogonia, oospores and antheridia were measured at 400x. The oospore wall index was calculated as the ratio between the volume of the oospore wall and the volume of the whole oospore (Dick 1990).

The preserved type materials of $P$. alticola available from the National Mycological Herbarium in Pretoria (PREM 59214, PREM 59215, PREM 59216, PREM 59217) were re-examined. The slides were rehydrated with $85 \%$ lactic acid and observed with a Zeiss Axioskop 2 Plus compound microscope fitted with an Axiocam MRc camera. Dimensions were measured using Axiovision v. 4.8 software.

\section{RESULTS}

\section{Phylogenetic analysis}

CMW 19417 was designated as the type isolate of Phytophora alticola by Maseko et al. (2007), but no sequence data were provided for this isolate. A subsequent sequence of this same isolate, CBS 121937 available on q-bank, actually corresponds to $P$. palmivora (Fig. 1). CMW 19424 and CMW 19425 were originally designated as paratypes and ITS sequence data were provided for these isolates. All of these isolates were subsequently lost except CMW 19425 $(=$ CBS $121939=$ CMW $34279=$ P19861 $)$. ITS sequence data for isolates presented with the original description, including CMW 19425 (DQ988196), differ by 3 bp from all recent sequences of CMW 34279, CBS 121939 and P19861 (Fig. 1). However, when resequenced CMW 19424 (= CBS 121938) was found to actually be an isolate of $P$. frigida (Fig 1). Based on ITS sequence data, the WA isolates investigated in this study cluster with either isolate CMW 34279 or with $P$. arenaria (Fig. 1).

BT sequences data was also provided in the original description (Maseko et al. 2007): all isolates assigned to $P$. alticola were identical, but differ by 2 bp from the new sequence of isolate CMW 34279 and by 4 bp from $P$. boodjera $\mathrm{sp}$. nov. (figure available on request from the authors). The coxl sequence of isolate CMW 34279 from three separate databases is identical and clusters separately from isolates assigned to $P$. boodjera sp. nov. (figure available on request from the authors). Isolates of $P$. arenaria cluster together, although intraspecific sequence variation is observed. In the concatenated dataset (Fig. 2), isolate CMW 34279 clusters with isolates of $P$. boodjera sp. nov., although it differs by 8 $\mathrm{bp}$ across the five gene regions examined. If the isolate is duplicated it forms a strongly supported cluster on its own (data not shown). Isolates of $P$. arenaria also reside in a strongly supported clade, although intraspecific variation is observed (Fig. 2).

\section{Status of Phytophthora alticola}

In 2008, the World Phytophthora Collection (WPC; http:// phytophthora.ucr.edu/default.html) was sent four isolates from the CMW collection, two isolates each of $P$. alticola and $P$. frigida. When the WPC sequenced them, they realised the identities were incorrect and informed the CMW collection (Table 2). Isolates of $P$. alticola and $P$. frigida were then checked in the CMW collection and it was discovered that all isolates of $P$. alticola had perished or were incorrectly identified, except for CMW19425 which was cleaned and renumbered CMW34279. This isolate was then sent to WPC where it was given the code P19861. Also in 2007, three isolates were sent to CBS; of these, the ex-holotype isolate CBS 121937 (= CMW 19417) is actually $P$. palmivora (the sequence associated with this isolate is available from q-bank), the ex-paratype isolate CBS 121938 (= CMW 19424) was not re-sequenced but is now determined as of $P$. frigida, leaving the same single isolate CBS 121939 (= CMW 34279) (Table 2).

At the start of this project, it was known that the exholotype isolate of $P$. alticola had perished, as indeed had all other isolates except an ex-paratype isolate CMW 19425 (= CMW 35429, = CBS 121939, = P19861). The ITS sequence of this isolate from all collections is identical, although there are a few bp different from the ITS sequence of the same isolate in the original description (Fig. 1). The sequence in the original description is short and the differences are at the end of the sequence and could have been erroneously labelled. Controversially, sequence data of other isolates in various collections designated as $P$. alticola match different species (Table 2).

It was originally considered that epitypification would be possible with the intention to designate CMW 34279 as the epitype. However, morphological examination of this isolate revealed that it differed from the original description: the sporangia are not caducous and chlamydospores are not produced (Table 3). Subsequent examination of the holotype and paratypes from PREM were inconclusive (Table 3). Each of the PREM types consisted of a semidried agar disc kept at $4{ }^{\circ} \mathrm{C}$ and a microscopic slide. The agar disks were all contaminated with bacteria and a dark hyphomycete, most of the mycelia had lysed, but a few aborted oospores were observed in PREM 59216 (= CMW 19424) and PREM 59217 (= CMW 19425). Some reproductive structures were present on the slides. Sporangia and chlamydospores were present for PREM 59214 (= CMW 19416) and PREM 59215 (= CMW 19417). The sporangia were predominantly ovoid, caducous and papillate, and produced in close sympodia (Table 3, Fig. $3)$. The dimensions of these sporangia match the original description of $P$. alticola (Maseko et al. 2007). However, in the original description the sporangia were described as borne on terminal or branched sporangiophores, while the slide associated with the holotype had sporangia borne 


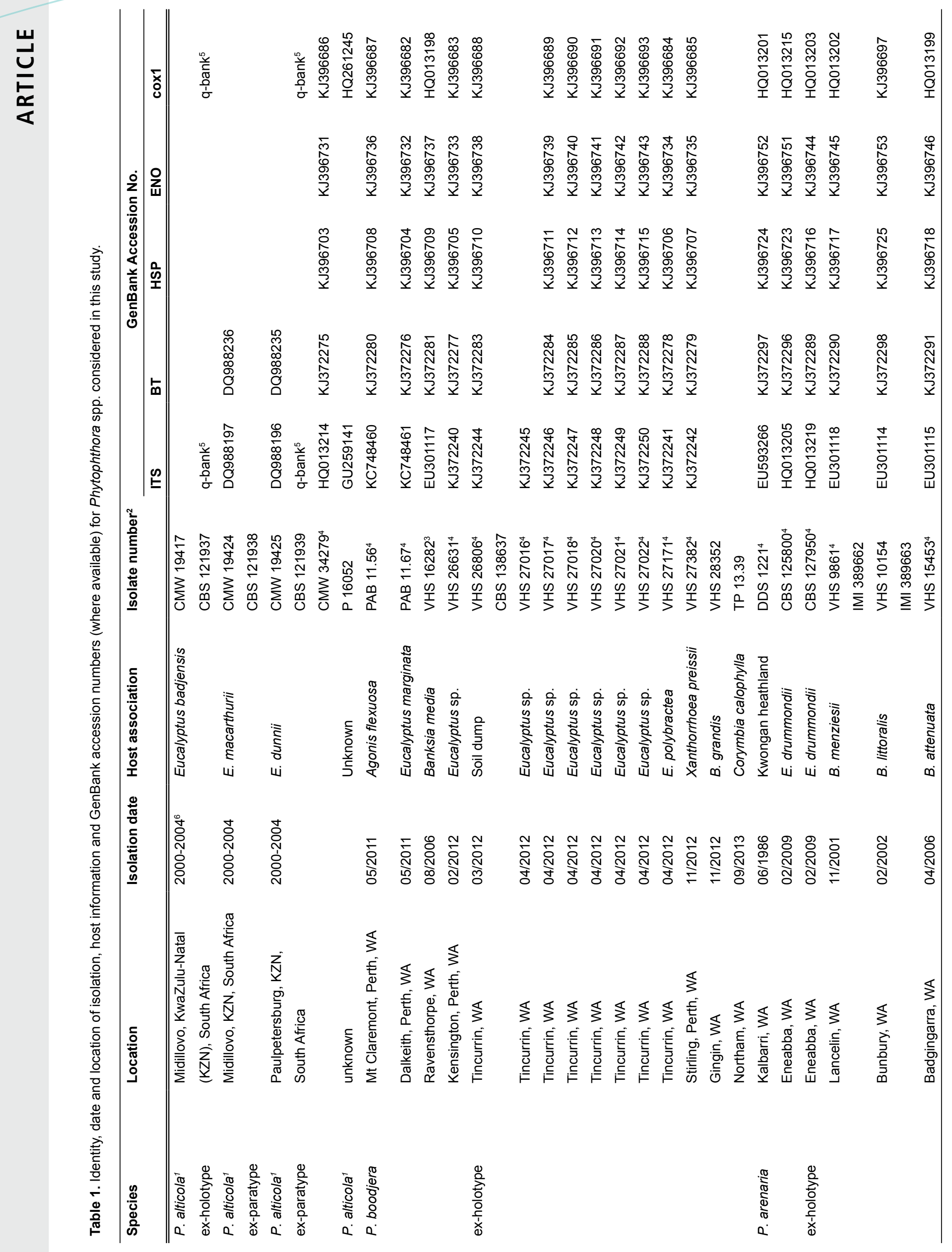




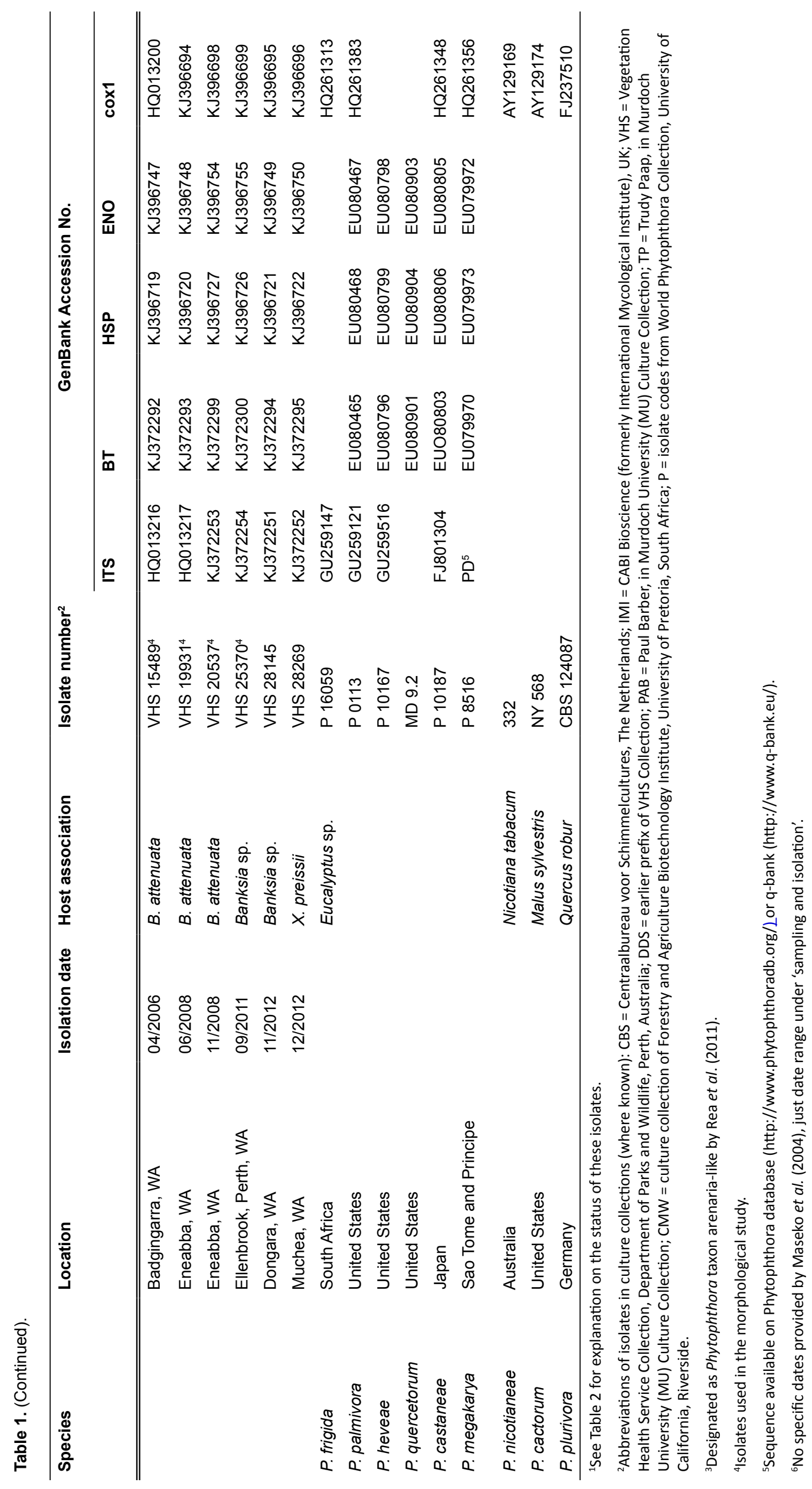




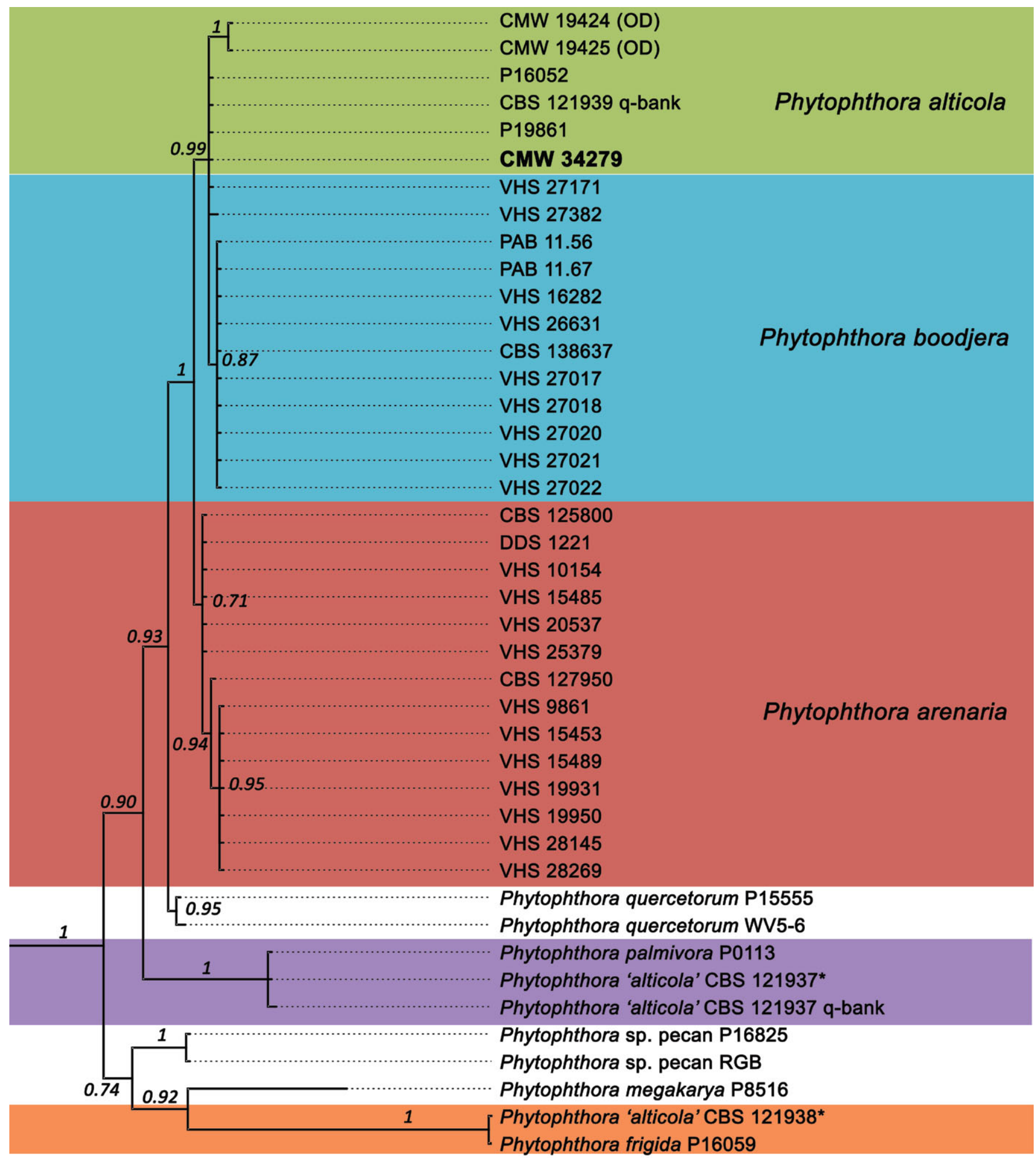

0.7

Fig. 1. Bayesian inference tree based on ITS sequence data generated in MrBayes using the GTR $+G$ substitution model showing relationship between $P$. alticola nom. dub. (green), $P$. boodjera sp. nov. (blue) and $P$. arenaria (red). Isolates designated as $P$. alticola in CBS correspond to $P$. palmivora (purple) and $P$. frigida (orange). The posterior probability is shown at the nodes. Phytophthora castaneae and $P$. heaveae were used as outgroup taxa. Asterisks indicate the re-sequenced isolates CBS 121937 and CBS 121938. CBS 121939 was resequenced, but not included as it was identical to the sequence on q-bank for this isolate.

in close sympodia. These sporangia and their branching patterns resemble more those produced by $P$. palmivora rather than those of living isolate CMW 34279 (Table 3,
Fig. 3). Oospores only were present in paratypes PREM 59216 (= CMW 19424) and PREM 59217 (= CMW 19425). The dimensions of these aplerotic oospores match the 


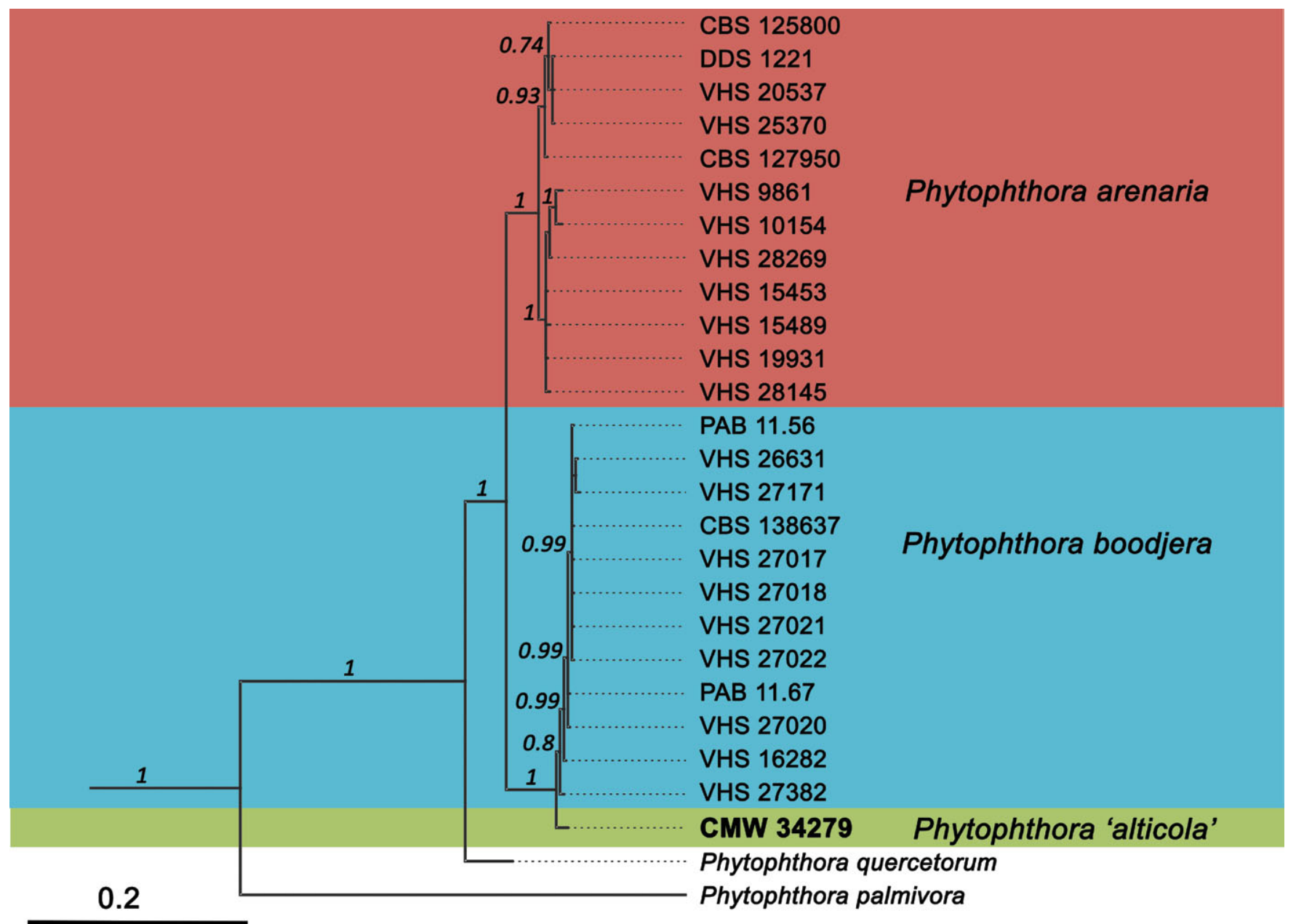

Fig. 2. Bayesian inference tree based on concatenated sequence data from ITS, $\beta$-tubulin, HSP90, enolase and coxl gene regions generated in MrBayes using the GTR $+G$ substitution model showing relationship between $P$. alticola nom. dub. (green), $P$. boodjera sp. nov. (blue) and $P$. arenaria (red). The posterior probability is shown at the nodes. Phytophthora castaneae and $P$. heaveae were used as outgroup taxa.

original description and those of living isolate CMW 34279 , however antheridia of the types are amphigynous, while those of CMW 34279 are paragynous (Table 3, Figs 3-4). Both $P$. frigida and $P$. alticola were described as having aplerotic oospores with amphigynous antheridia (Table 3 ), therefore the slides associated with the paratypes are inconclusive.

In the original description (Maseko et al. 2007), no sequence data were provided for PREM 59214 (= CMW 19416) and PREM 59215 (= CMW 19417). When the exholotype isolate was submitted to CBS and sequenced for q-bank (CBS 121937) it was found to be an isolate of $P$. palmivora (Fig. 1, Table 2). Caducous, papillate sporangia and chlamydospores matching $P$. palmivora were observed in PREM 59214 (= CMW 19416) and PREM 59215 (= CMW 19417) (Fig. 3). When the ex-paratype isolate CMW 19424 was submitted to CBS it was found to be $P$. frigida, as were several isolates labelled as $P$. alticola that were sent to WPC (Fig. 1, Table 2). Phytophthora frigida also has aplerotic oogonia with amphigynous antheridia, as observed for PREM 59216 (= CMW 19424) and PREM 59217 (= CMW 19425). Thus, we believe that while in the original description of $P$. alticola the sequence data provided was identical for all isolates, the actual morphological description is based on a set of isolates from more than one species; these are most probably $P$. palmivora, P. frigida, and a species represented by isolate CMW 34279. As there are no other living isolates linked to the original description available for examination and as no more isolates have been recovered in South Africa, despite extensive sampling, it is not possible to amend the description of $P$. alticola or to designate PREM 59217 (= CMW 19425, = CMW 35429) as an epitype. At this point in time the application of the name $P$. alticola is in doubt and will remain so until more isolates from similar hosts or locations can be made and this taxon will be referred to hereafter as $P$. alticola nom. dub.

Compared with the description of $P$. alticola nom. dub., CMW 34279 has a higher optimum temperature for growth, faster growth rate, persistent sporangia, no chlamydospores and paragynous antheridia, and is very similar in morphology to isolates from Australia described here as $P$. boodjera. 


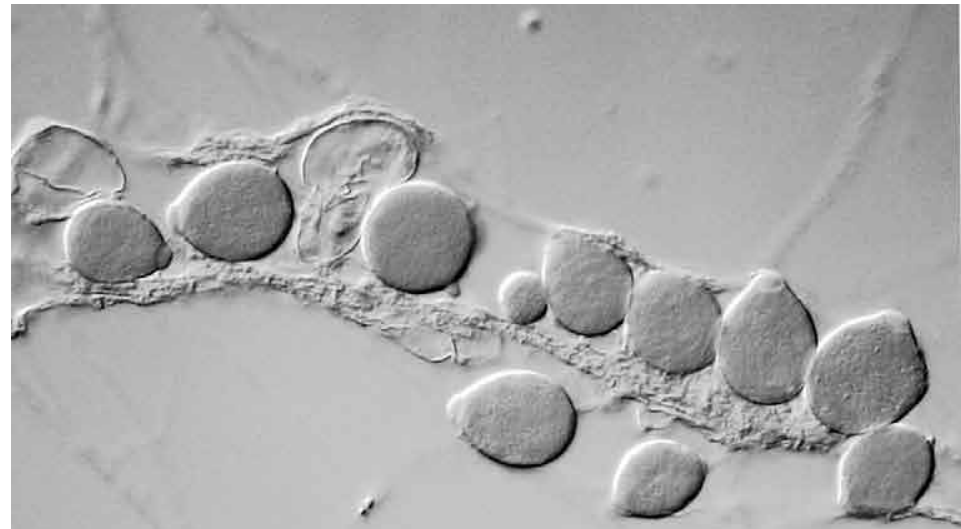

A
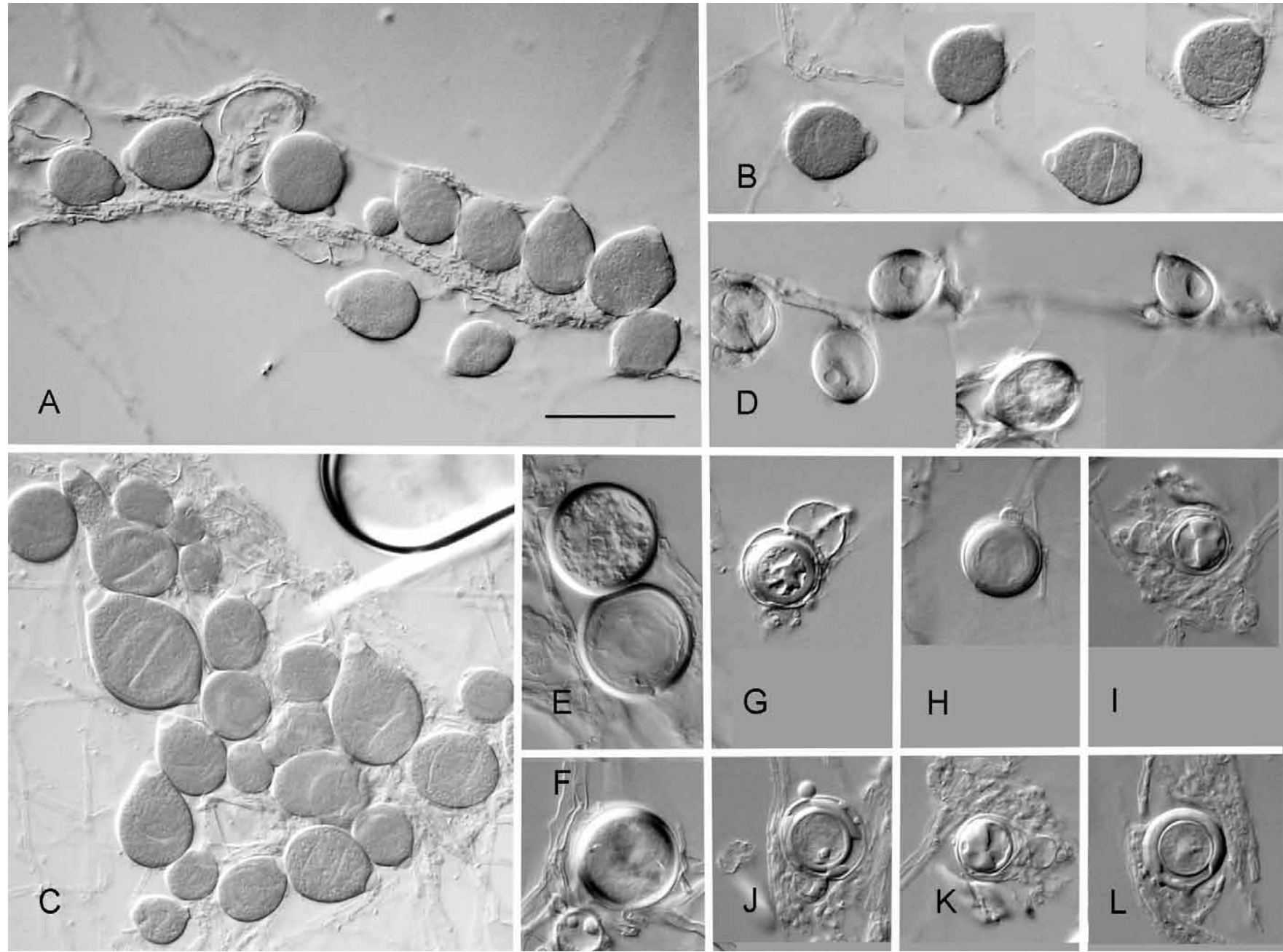

Fig. 3. Rehydrated slides of $P$. alticola nom. dub. (type specimens). Sporangia of paratype PREM $59214=$ CMW 19416: (a) close sympodia with papillate, ovoid sporangia, (b) papillate, ovoid caducous sporangia with short pedicels, (c) papillate ovoid sporangia. Sporangia and chlamydospores of holotype PREM 59215 = CMW 19417: (d) Papillate, ovoid sporangia, (e-f) chlamydospores. Oospores of paratype PREM 59216 = CMW 19424: $(\mathrm{g}-\mathrm{h})$ aplerotic oospores with amphigynous antheridia. Oospores of paratype PREM $59217=$ CMW 19425: $(\mathrm{i}-\mathrm{I})$ aplerotic oospores with amphigynous antheridia. Bar $=50 \mu \mathrm{m}$.

\section{TAXONOMY}

Phytophthora boodjera A.V. Simamora \& T.I. Burgess, sp. nov.

MycoBank MB809223

(Figs 4-5)

Etymology: the species name is derived from the Noongar (local Aboriginal) name for earth, ground, or sand plain.

Type: Australia: Western Australia: Tincurrin, from nursery soil dump, Mar. 2012, collected by the Vegetation Health Service of the Department of Parks and Wildlife (MURU 470-holotype; cultures ex-type CBS $138637=$ VHS 26806). ITS, B-tubulin, HSP90, enolase and coxl sequence GenBank KJ372244, KJ372283, KJ396710, KJ396738 and KJ396688 respectively).

Diagnosis: $P$. boodjera is phylogenetically closely related to $P$. alticola nom. dub. but differs in having persistent sporangia, paragynous antheridia and no chlamydospores. $P$. boodjera is morphologically similar to $P$. arenaria but differs in having a higher lethal temperature and larger sporangia and oogonia.

Description (type): Papillate, persistent predominantly ovoid sporangia (52 \%) but also limoniform (45\%) and distorted shapes (3\%). Sporangia averaged $34.7 \pm 1.16 \times 27 \pm 0.78 \mu \mathrm{m}$ and ranged 15.2-62.3 x 14.6-42.5 $\mu \mathrm{m}$. Homothallic; aplerotic oogonia averaged $28.9 \pm 2.13 \mu \mathrm{m}$, ranging from $24.3-34$ $\mu \mathrm{m}$. Oospores averaging $26.3 \pm 1.42 \mu \mathrm{m}$ diam, range 20.9 $29.4 \mu \mathrm{m}$. Growth rate at optimum of $25^{\circ} \mathrm{C}$ was $11.2 \mathrm{~mm} / \mathrm{d}$. Colonies were appressed with no pattern and had regular smooth margins on CA, V8A, MEA and PDA.

Description (species): Sporangia papillate, persistent, abundantly produced in soil extract water on simple sporangiophores frequently with globose swellings close to the sporangial base (Fig. 4f). Although predominantly ovoid (64\%, Fig. 4a-g), various sporangial shapes were observed including limoniform (20\%, Fig. 4d right, 4h), peanut-shaped $(10 \%)$ and distorted shapes (6\%, Fig. 4i, j). Bipapillate (Fig. 4i) sporangia were also occasionally observed. 


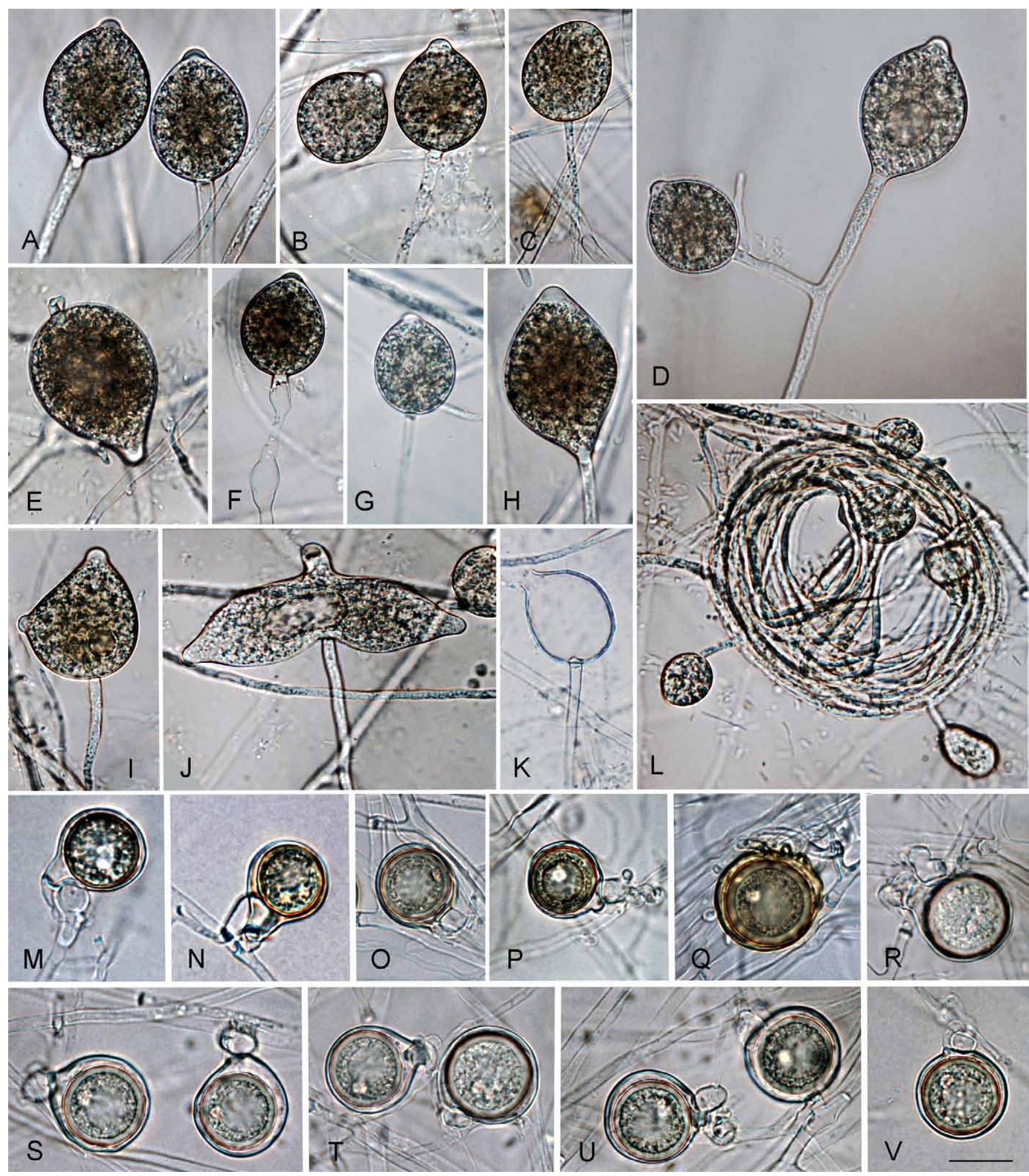

D
금
Г

Fig. 4. (a-k) Papillate sporangia of Phytophora boodjera formed on V8A flooded with soil extract. Ovoid to broadly ovoid (a, b, e, f, g), limoniform (d right, h) bipapillate (i) distorted and bipapillate (j) often with laterally attached sporangiophore (c, k). Branching sporangiophores were rarely observed (d), occasional constriction of sporangiophore near base of sporangia (e), or bulbous sporangiophore (f). Hyphal coils rarely observed (I). Oogonia of $P$. alticola nom. dub. isolate CMW34279 with tapering bases, wavy margins and turning golden brown at maturity, with aplerotic oospores and paragynous antheridia $(\mathrm{m}-\mathrm{q})$. Aplerotic oospores of $P$. boodjera with paragynous antheridia $(\mathrm{r}-\mathrm{v})$. Scale bar $=20 \mu \mathrm{m}$.

Sporangiophores often laterally attached to sporangia (Fig. 4c, k), and sometimes constricted (Fig. 4e); branched sporangiophores rare (Fig. 4d). Sporangia from 12 isolates averaged $39.2 \pm 4.4 \times 29.7 \pm 3.4 \mu \mathrm{m}$ (range $32.5-44.5 \times$
24.5-33.5 $\mu \mathrm{m}$ ), exit pores narrow, $6 \pm 1 \mu \mathrm{m}$, length:breadth ratio $1.27 \pm 0.16$ (Table 3 ). Chlamydospores absent.

Homothallic, readily producing oogonia (and sporangia) in single culture on CA and V8A. Oospores matured within 14 

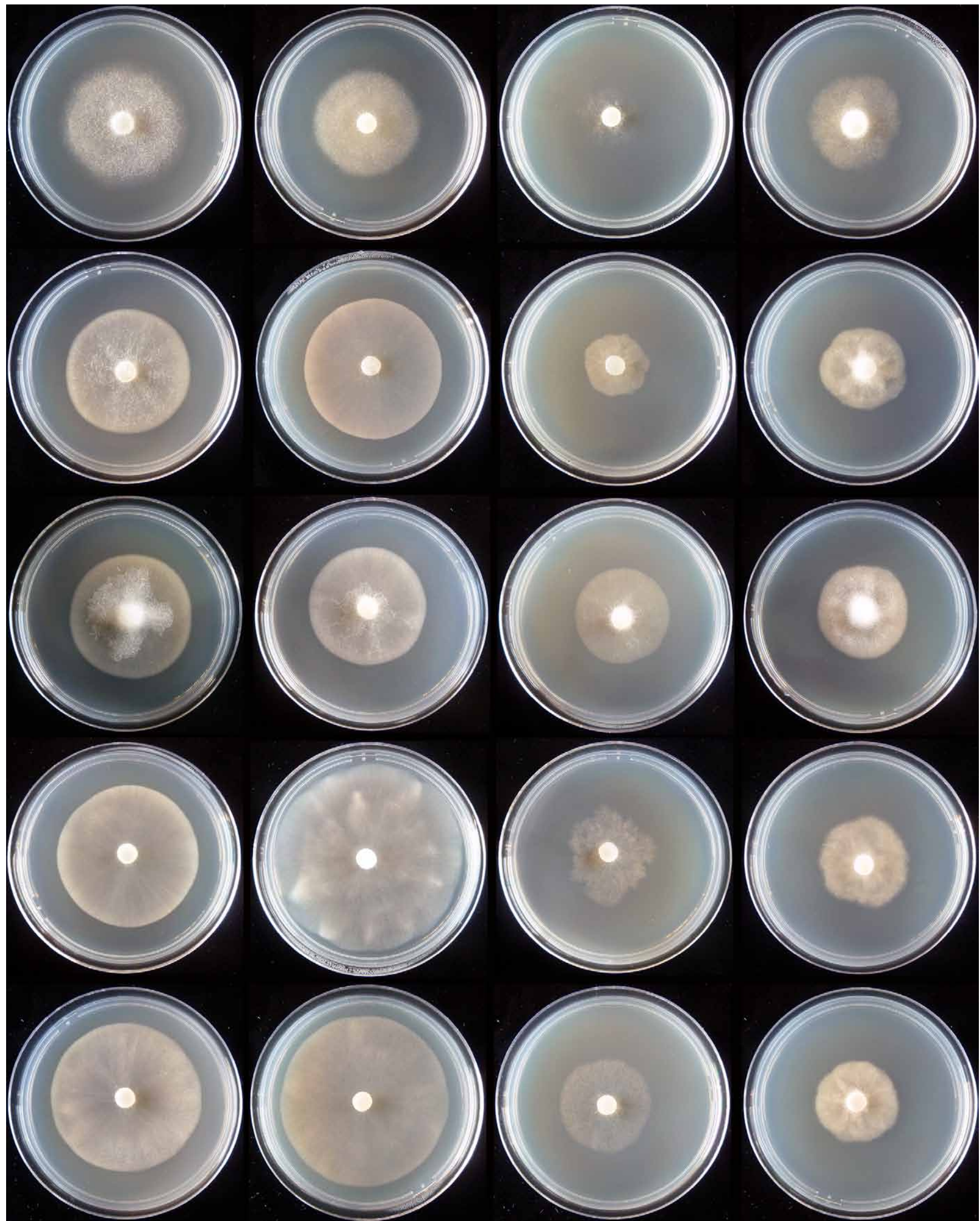

Fig. 5. Colony morphology of (top to bottom) isolate CMW 34279, Phytophthora boodjera (VHS 27171, CBS 138637), and P. arenaria (CBS 127950, VHS 25370) after $7 \mathrm{~d}$ growth at $20^{\circ} \mathrm{C}$ on different media: CA, V8A, MEA and half strength PDA (left to right).

to $21 \mathrm{~d}$. Oogonia averaged $29.4 \pm 2.3 \mu \mathrm{m}$ diam with isolate means ranging from 24.6 to $33.4 \mu \mathrm{m}$ (Table 3 ). Oospores aplerotic in all isolates, containing ooplasts when semi- mature to mature (Fig. $4 \mathrm{~s}-\mathrm{v}$ ). Oospores averaged $25.5 \pm 1.9$ $\mu \mathrm{m}$ diam with isolate means ranging from 21.3 to $29.5 \mu \mathrm{m}$ (Table 3). Oospore walls thick $(2.5 \pm 0.33 \mu \mathrm{m})$ (Fig. $4 \mathrm{~s}-\mathrm{v})$, 
Table 2. Status of Phytophthora alticola isolates submitted to different culture collections.

\begin{tabular}{|c|c|c|}
\hline Isolate & Sequence $^{1}$ & Notes on status of isolate \\
\hline $\begin{array}{l}\text { CMW } 19416 \\
\text { PREM 59214-paratype }\end{array}$ & no sequence (OD) & $\begin{array}{l}\text { Lost in CMW collection. Only papillate, caducous sporangia and } \\
\text { chlamydospores observed from preserved slide associated with PREM } 59214\end{array}$ \\
\hline $\begin{array}{l}\text { CMW } 19417 \\
\text { PREM } 59215 \text {-holotype } \\
\text { CBS } 121937\end{array}$ & $\begin{array}{l}\text { no sequence (OD) } \\
\text { ITS, CO, YPT1, TEF } \\
\text { (q-bank) }\end{array}$ & $\begin{array}{l}\text { Lost in CMW collection. Supposed corresponding isolate in CBS is actually } \\
P \text {. palmivora and all sequence data on q-bank associated with this isolate is } P \text {. } \\
\text { palmivora. Only papillate, caducous sporangia and chlamydospores observed } \\
\text { from preserved slide associated with PREM } 59215\end{array}$ \\
\hline $\begin{array}{l}\text { CMW } 19419 \\
\text { PD } 01642\end{array}$ & ITS and BT (OD) & Lost in CMW collection \\
\hline $\begin{array}{l}\text { CMW } 19421 \\
\text { PD } 01641\end{array}$ & ITS and BT (OD) & Lost in CMW collection \\
\hline $\begin{array}{l}\text { CMW } 19422 \\
\text { PD } 01640\end{array}$ & ITS and BT (OD) & Lost in CMW collection \\
\hline $\begin{array}{l}\text { CMW } 19423 \\
\text { PD } 01639\end{array}$ & ITS and BT (OD) & Lost in CMW collection \\
\hline $\begin{array}{l}\text { CMW } 19424 \\
\text { PREM } 59216 \text {-paratype } \\
\text { CBS } 121938 \\
\text { PD } 01638\end{array}$ & ITS and BT (OD) & $\begin{array}{l}\text { Lost in CMW collection. Sequence on q-bank of ITS and BT is from } \\
\text { the original description. The ITS of isolate re-sequenced in this study } \\
\text { corresponds to } P \text {. frigida. Only aplerotic oospores and amphigynous } \\
\text { antheridia observed from preserved slide associated with PREM59216 }\end{array}$ \\
\hline $\begin{array}{l}\text { CMW } 19425 \\
\text { PREM } 59217 \text {-paratype } \\
\text { CBS } 121939 \\
\text { PD } 01637\end{array}$ & $\begin{array}{l}\text { ITS and BT (OD) } \\
\text { ITS, CO, YPT1, TEF } \\
\text { (q-bank) }\end{array}$ & $\begin{array}{l}\text { Living in CMW collection and renamed CMW } 35429 \text {. ITS and BT of re- } \\
\text { sequenced isolate differ from original description by } 3 \text { and } 2 \text { bp respectively. } \\
\text { ITS and CO sequence on q-bank is identical to sequence of isolate } \\
\text { CMW } 35429 \text { obtained in the current study. Only aplerotic oospores and } \\
\text { amphigynous antheridia observed from preserved slide associated with } \\
\text { PREM } 59217\end{array}$ \\
\hline $\begin{array}{l}\text { CMW } 35429 \\
\text { P16948 }\end{array}$ & $\begin{array}{l}\text { ITS, cox1, ENO, HSP, BT } \\
\text { ITS (GA) }\end{array}$ & $\begin{array}{l}\text { Was sent to WPC as CMW } 35429 \text { as a replacement for } P \text {. alticola and named } \\
\text { WPC } 16948 \text {. ITS sequence supplied by Gloria Abad is identical to that } \\
\text { obtained in the current study for isolate CMW } 35429\end{array}$ \\
\hline $\begin{array}{l}\text { PD } 01914 \\
\text { P16053 }\end{array}$ & $\operatorname{cox} 2$ and $\operatorname{cox} 1(P D)$ & $\begin{array}{l}\text { Was sent to WPC as } P \text {. alticola isolate CMW } 19424 \text { but when sequenced it } \\
\text { was identified as being an isolate of } P \text {. frigida }\end{array}$ \\
\hline $\begin{array}{l}\text { PD } 02043 \\
\text { P16051 }\end{array}$ & $\operatorname{cox} 2$ and $\operatorname{cox} 1(P D)$ & $\begin{array}{l}\text { Was sent to WPC as } P \text {. frigida isolate CMW } 19433 \text { and when sequenced it } \\
\text { was identified as being an isolate of } P \text {. frigida }\end{array}$ \\
\hline $\begin{array}{l}\text { PD } 02044 \\
\text { P16054 }\end{array}$ & $\operatorname{cox} 2$ and $\operatorname{cox} 1(P D)$ & $\begin{array}{l}\text { Was sent to WPC as } P \text {. alticola isolate CMW } 19425 \text { but when sequenced it } \\
\text { was identified as being an isolate of } P \text {. frigida }\end{array}$ \\
\hline $\begin{array}{l}\text { PD } 02775 \\
\text { P16052 }\end{array}$ & $\operatorname{cox} 1(P D)$ & $\begin{array}{l}\text { Was sent to WPC as } P \text {. frigida isolate CMW } 20311 \text { but when sequenced it } \\
\text { was identified as being an isolate of } P \text {. alticola and thus cannot be linked to } \\
\text { any isolate from CMW collection }\end{array}$ \\
\hline $\begin{array}{l}\text { VHS } 26631 \\
\text { P19861 }\end{array}$ & ITS, cox1, ENO, HSP, BT & $\begin{array}{l}\text { List in WPC as a neotype for } P \text {. alticola, but this is not recommended as } \\
\text { the isolate is from a different host and a different country from the original } \\
\text { description. In current study this is considered an isolate of } P \text {. boodjera. }\end{array}$ \\
\hline
\end{tabular}

${ }^{1} \mathrm{OD}=$ original description (Maseko et al. 2007), WPC = World Phytophthora Collection (http://phytophthora.ucr.edu/), GA = supplied by Gloria Abad, PD = Phytophthora database http://www.phytophthoradb.org/, q-bank = http://www.q-bank.eu/.

oospore wall index $0.47 \pm 0.05 \mu \mathrm{m}$ (Table 3). Antheridia paragynous (Fig. $4 \mathrm{r}-\mathrm{v}$ ), averaging $10.4 \pm 1.9 \times 8.3 \pm 1.5 \mu \mathrm{m}$. Hyphal swellings catenulate, some with radiating hyphae, formed rarely in non-sterile soil extract water.

Cultures: All isolates produced colonies that were appressed with no distinctive growth pattern and regular smooth margins on CA, V8A, MEA, and PDA (Fig. 5). Growth on MEA was sparser than on the other media. Optimum temperature for the growth on V8A $25-30{ }^{\circ} \mathrm{C}$, where the average growth rate was $9.18 \pm 0.56 \mathrm{~mm} / \mathrm{d}$ (Fig. 6). The maximum temperature for growth was $35^{\circ} \mathrm{C}$ (Table 3). Although no growth occurred at $37.5^{\circ} \mathrm{C}$, this temperature was not lethal since isolates resumed growth when subsequently incubated at $20^{\circ} \mathrm{C}$.

Additional specimens examined: Australia: Western Australia: Mt Claremont, Perth, from roots of dying Agonis flexuosa, May 2011, Paul Barber (PAB 11.56, private collection); Dalkeith, from roots of dying Eucalyptus marginata, May 2011 Paul Barber (PAB 11.67, private collection); Northam, from Corymbia calophylla, Sept. 2013,Trudy Paap (TP13.39, private collection). Ravensthorpe, from Banksia media, Aug. 2006, (VHS 16282); Kensington, Perth, WA, from Eucalyptus sp., Feb. 2012, (VHS 26631); Tincurrin, from Eucalyptus spp., Apr. 2012, (VHS 27016, VHS 27017, VHS 27018, VHS 27020, VHS 27021, VHS 27022); Tincurrin, from roots of E. polybractea, Apr. 2012, (VHS 27171); Stirling, 


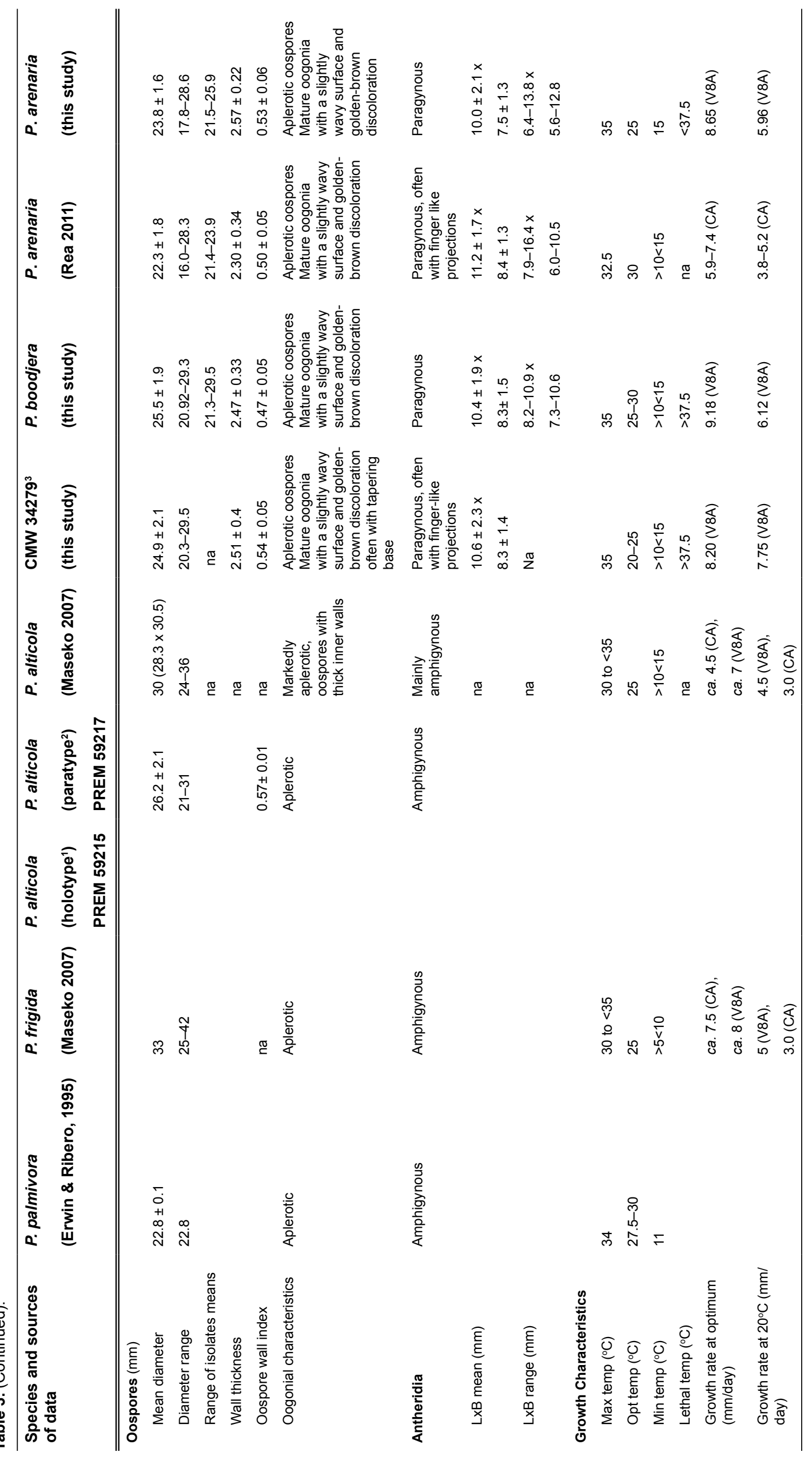




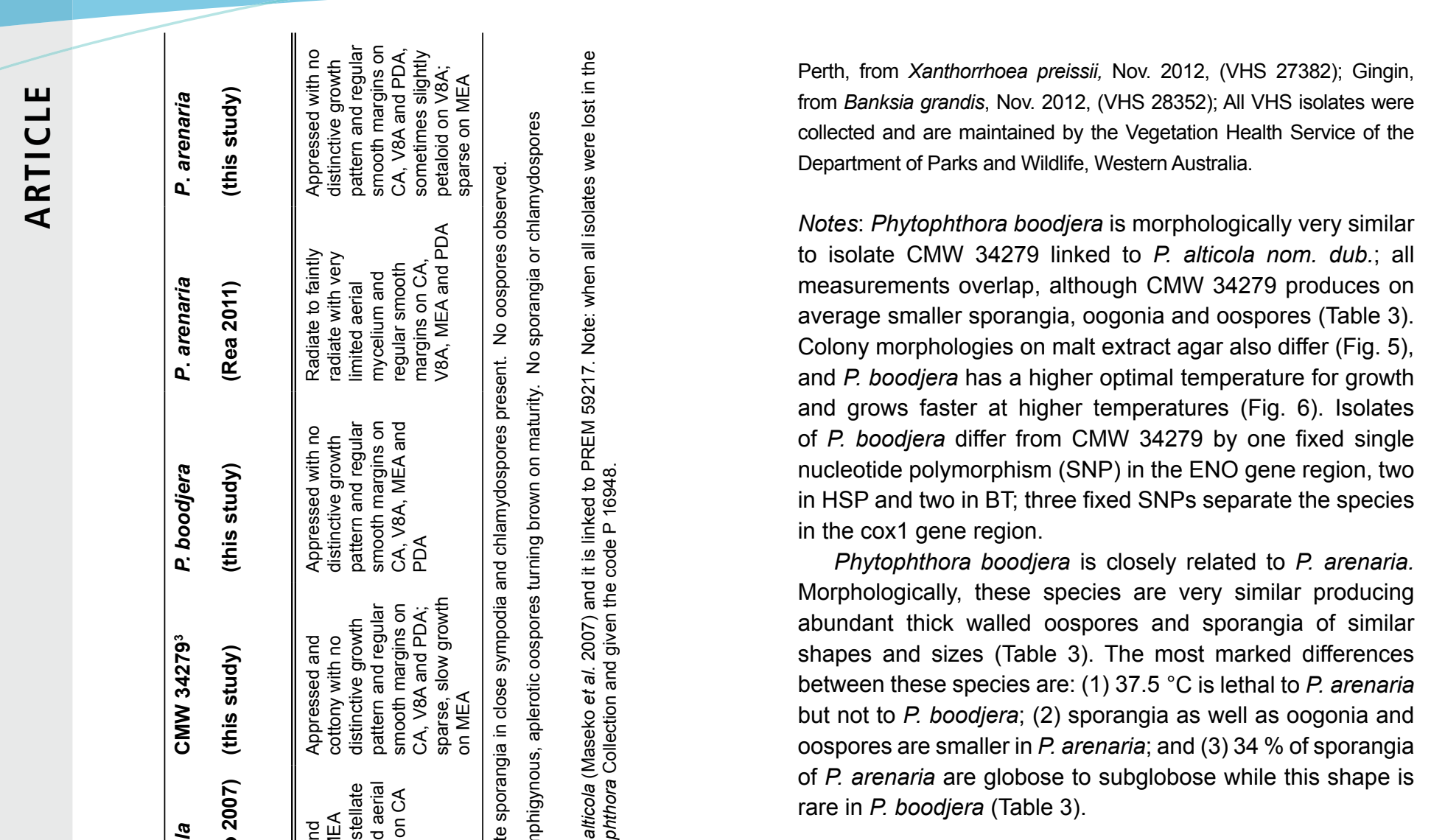

\section{DISCUSSION}

Phytophthora isolates from plant production nurseries in Western Australia (WA) were identified as closely related to P. alticola nom. dub. based on ITS sequence data. These isolates were compared to the single remaining isolate of P. alticola nom. dub. from the original description (Maseko et al. 2007). Based on morphology and molecular data from four nuclear and one mitochondrial gene region, the isolates from WA were recognized as a new species and described as $P$. boodjera. Phytophthora boodjera has emerged as a pathogen in some WA plant production nurseries and is now regularly recovered also from urban environments. However, it has been recovered infrequently (VHS 16282 from Ravensthorpe, VHS 28352 from Gingin, and TP 13.39 from Northam) from natural ecosystems in WA, despite widespread sampling in the region (Burgess et al. 2009, Rea et al. 2011).

Phytophthora alticola nom. dub. was originally described from Eucalyptus plantations in South Africa and has never been recovered from sampling within natural ecosystems in that region (Nagel et al. 2013, Oh et al. 2013). This suggests that $P$. alticola has been introduced into South Africa. Morphological studies of the remaining isolate CMW 34279 revealed three major discrepancies with the original description: firstly, P. alticola nom. dub. was described as having caducous sporangia, and secondly, as producing chlamydospores; however, the remaining isolate CMW 34279 has persistent sporangia and produced no chlamydospores. Thirdly, P. alticola nom. dub. was described as producing mainly amphigynous and some paragynous antheridia; however, in the remaining isolate CMW 34279 , only paragynous 


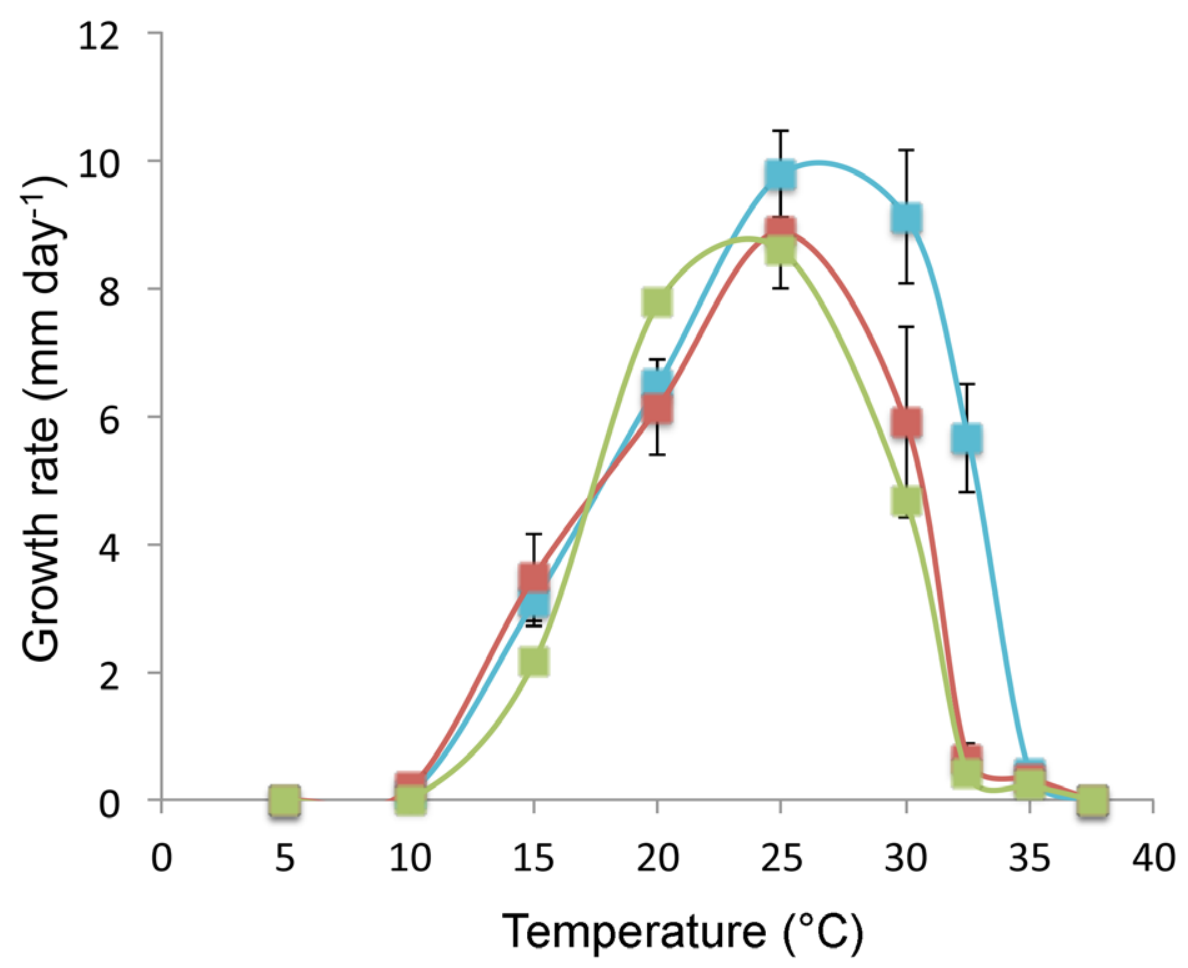

Fig. 6. Average growth rate $(\mathrm{mm} / \mathrm{d} \pm \mathrm{SE})$ of Phytophthora boodjera (blue), CMW 34279 (green) and $P$. arenaria (red) on V8A across the temperature range from $4-37.5^{\circ} \mathrm{C}$.

antheridia were observed. Although the ex-holotype isolate CMW 19417 has been lost, re-examination of the holotype PREM 59215 revealed sporangia and chlamydospores matching the original description of $P$. alticola nom. dub. except that they were produced in close sympodia rather than simple or branched sympodia (Maseko et al. 2007). CMW 19417 was submitted to CBS and the sequence of this isolate reveals that it is $P$. palmivora. The dimensions and characteristics of sporangia and chlamydospores observed in the holotype match those of $P$. palmivora.

Discrepancies in sequence data were found between the original description of $P$. alticola nom. $d u b$. and the remaining ex-paratype isolate CMW 19425 (= CMW 34279). Unfortunately only oospores can be observed on the paratype PREM 59217 (= CMW 19425), but even these differ from the original description in that all antheridia are amphigynous in the holotype material, but they are all paragynous for CMW 34279. Thus, after examining the holotype and paratype material and resequencing isolates submitted to CBS, we have concluded that the original description was based on a mix of species and, as no further isolates similar to CMW 34279 have been recovered in South Africa despite extensive sampling (Oh et al. 2013), the status of $P$. alticola is in doubt.

Phytophthora arenaria (Rea et al. 2011), the species most closely related to $P$. boodjera in Western Australia, has been recovered exclusively from natural Kwongan vegetation on the coastal sand plains of south-west WA, where it was mainly isolated from dead and dying Banksia species and from the rhizosphere soil associated with such plants. This species appears to be restricted to the Kwongan vegetation and to be adapted to this ecosystem, suggesting that $P$. arenaria is native to WA. Phytophthora boodjera has only recently been found in WA and has mostly been isolated from dead and dying eucalypt seedlings in plant production nurseries and from declining trees (predominantly Myrtaceae) in disturbed urban landscapes, and once from Xanthorrhoea preissii. It has been isolated from natural ecosystems on only three occasions (from Banksia media, B. grandis, and Corymbia calophylla) and currently we consider this to be an introduced species.

Recent outbreaks of the damping-off disease of young eucalypt seedlings, caused by $P$. boodjera, have raised new concerns about the risk of Phytophthora species in plant production nurseries in WA. The dispersal of Phytophthora from nurseries to field plantings in previously non-infested areas may result in serious threats to biodiversity in natural ecosystems in these areas.

\section{ACKNOWLEDGEMENTS}

Trudy Paap, Keith Parnell, and Paul Barber were all involved in the collection of isolates for this study. Mike Coffey, Gloria Abad, Seonju Marincowitz and Arthur de Cock have all provided valuable help and discussion in resolving the current status of Phytophthora alticola. Diane White is thanked for technical assistance. A.S. thanks DIKTI program from the Indonesian Government for a PhD Scholarship.

\section{REFERENCES}

Aghighi S, Hardy GESJ, Scott JK, Burgess TI (2012) Phytophthora bilorbang sp. nov., a new species associated with the decline of Rubus anglocandicans (European blackberry) in Western Australia. European Journal of Plant Pathology 133: 841-855.

Andjic V, Cortinas M-N, Hardy GESJ, Wingfield MJ, Burgess TI (2007) Multiple gene genealogies reveal important relationships between species of Phaeophleospora infecting Eucalyptus leaves. FEMS Microbiology Letters 268: 22-33. 
Barber P, Burgess TI, Paap T, Hardy GESJ (2012) Phytophthora species associated with disease in peri-urban woodland and forest ecosystems. In: 6th International Meeting IUFRO Working Party 7.02.09. Phytophthora in Forests and Natural Ecosystems, 9-14th September Cordoba, Spain: 84.

Blair JE, Coffey MD, Park S, Geiser DM, Kang S (2008) A multilocus phylogeny for Phytophthora utilizing markers derived from complete genome sequences. Fungal Genetics and Biology 45: 266-277.

Brasier CM, Denman S, Brown A, Webber JF (2004) Sudden oak death (Phytophthora ramorum) discovered on trees in Europe. Mycological Research 108: 1108-1110.

Brasier CM (2008) The biosecurity threat to the UK and global environment from international trade in plants. Plant Pathology 57: 792-808.

Burgess TI, Webster JL, Ciampini JA, White DW, Hardy GESJ, et al. (2009) Re-evaluation of Phytophthora species isolated during 30 years of vegetation health surveys in Western Australia using molecular techniques. Plant Disease 93: 215-223.

Burgess TI, Hüberli D, Hardy GESJ, Stukely MJC, Jung T (2012) Phytophthora amnicola T.I. Burgess \& T. Jung, sp. nov. [Fungal Planet description sheets: 107.] Persoonia 28: 140-141.

Cooke DEL, Drenth A, Duncan JM, Wagels G, Brasier CM (2000) A molecular phylogeny of Phytophthora and related oomycetes. Fungal Genetics and Biology 30: 17-32.

Crous PW, Summerell BA, Shivas RG, Burgess TI, Decock CA, et al. (2012) Fungal Planet description sheets: 107-127. Persoonia 28: $138-182$.

Darriba D, Taboada GL, Doallo R, Posada D (2012) jModelTest 2: more models, new heuristics and parallel computing. Nature Methods 9: 772-772.

Davison WM, Drenth A, Kumar S, Mack S, Mackie AE, et al. (2006) Pathogens associated with nursery plants imported into Western Australia. Australasian Plant Pathology Society 35: 473-475.

Dick MW (1990) Keys to Pythium. Reading: University of Reading Press.

Erwin DC, Ribeiro OK (1996) Phytophthora Diseases Worldwide. St Paul, MN: American Phytopathological Society Press.

Goss EM, Larsen M, Vercauteren A, Werres S, Heungens K, et al. (2011) Phytophthora ramorum in Canada: Evidence for migration within North America and from Europe. Phytopathology 101: 166-171.

Grünwald NJ, Garbelotto M, Goss EM, Heungens K, Prospero $S$ (2012) Emergence of the sudden oak death pathogen Phytophthora ramorum. Trends in Microbiology 29: 131-138.

Hardy GESJ, Sivasithamparam K (1998) Phytophthora spp. associated with container-grown plants in nurseries in Western Australia. Plant Disease 72: 435-437.

Hüberli D, Tommerup IC, Hardy GESJ (2000) False-negative isolations or absence of lesions may cause mis-diagnosis of diseased plants infected with Phytophthora cinnamomi. Australasian Plant Pathology 29: 164-169.

Hüberli, D, Hardy GESJ, White D, Williams N, Burgess TI (2013) Fishing for Phytophthora from Western Australia's waterways: a distribution and diversity survey. Australasian Plant Pathology 42: $251-260$.

Jung T, Stukely MJC, Hardy GESJ, White D, Paap T, et al. (2011a) Multiple new Phytophthora species from ITS Clade 6 associated with natural ecosystem in Australia: evolutionary and ecological implications. Persoonia 26: 13-39.
Jung, T, Burgess TI, Hüberli D, Hardy GESJ, Stukely MJC (2011b) Phytophthora fluvialis T. Jung \& T.I. Burgess, sp. nov. [Fungal Planet description sheets: 87.] Persoonia 26: 146-147.

Kroon LPNM, Bakker FT, van den Bosch GBM, Bonants PJM, Fliera WG (2004) Phylogenetic analysis of Phytophthora species based on mitochondrial and nuclear DNA sequences. Fungal Genetics and Biology 41: 766-782.

Kroon LP, Brouwer H, de Cock A, Govers F (2012) The genus Phytophthora anno 2012. Phytopathology, 102: 348-364.

Leonberger AJ, Speers C, Ruhl G, Creswell T, Beckerman JL (2013) A survey of Phytophthora spp. in Midwest nurseries, greenhouses, and landscapes. Plant Disease 97: 635-640.

Liebhold AM, Brockerhoff EG, Garret LJ, Parke JL, Britton KO (2012) Live plant imports: the major pathway for forest insect and pathogen invasion of the US. Frontiers in Ecology and the Environment 10: 135-143.

Lilja A, Rytkönen A, Hantula J, Müller M, Parikka P, et al. (2011) Introduced pathogens found on ornamentals, strawberry and trees in Finland over the past 20 years. Agriculture and Food Science 20: 74-85.

Martin FN, Tooley PW (2003) Phylogenetic relationships among Phytophthora species inferred from sequence analysis of mitochondrially encoded cytochrome oxidase I and II genes. Mycologia 95: 269-284.

Maseko B, Coutinho TA, Burgess TI, Wingfield BD, Wingfield MJ (2007) Two new species of Phytophthora from South African eucalypt plantations. Mycological Research 111: 1321-1338.

Moralejo E, Perez-Siera AM, Álvarez LA, Belbahri L, Lefort F, et al. (2009) Multiple alien Phytophthora taxa discovered on diseased ornamental plants in Spain. Plant Pathology 58: 100-110.

Nagel JH, Gryzenhout M, Slippers B, Wingfield MJ (2013) The occurrence and impact of Phytophthora on the African continent. In: Phytophthora: a global perspective (Lamour K, ed.): 204-214. Wallingford: $C A B$ International.

Oh E, Gryzenhout M, Wingfield WD, Wingfield MJ, Burgess TI (2013) Surveys of soil and water reveal a goldmine of Phytophthora diversity in South African ecosystems. IMA Fungus 4: 123-131.

Parke J, Lucas S (2008) Sudden oak death and ramorum blight. The Plant Health Instructor. DOI: 10.1094/PHI-I-2008-0227-01.

Parke JL, Grünwald NJ (2012) A systems approach for management of pests and pathogens of nursery crops. Plant Disease 96: 1236-1244.

Pérez-Sierra A, Jung T (2013) Phytophthora in woody ornamental nurseries. In: Phytophthora: a global perspective (Lamour K, ed.): 166-177. Wallingford: CAB International.

Prospero S, Vercauteren A, Heungens K, Belbahri L, Rigling D (2013) Phytophthora diversity and population structure of Phytophthora ramorum in Swiss ornamental nurseries. Plant Pathology 62: 1063-1071.

Rea AJ, Jung T, Burgess TI, Stukely MJC, Hardy GESJ (2010) Phytophthora elongata sp. nov., a novel pathogen from the Eucalyptus marginata forest of Western Australia. Australasian Plant Pathology 39: 477-491.

Rea AJ, Burgess TI, Hardy GESJ, Stukely MJC, Jung T (2011) Two novel and potentially endemic species of Phytophthora associated with episodic dieback of Kwongan vegetation in the south-west of Western Australia. Plant Pathology 60: 1055-1068.

Rizzo DM, Garbelotto M, Davidson JM, Slaughter GW, Koike ST (2002) Phytophthora ramorum as the cause of extensive mortality 
of Quercus spp and Lithocarpus densiflorus in California. Plant Disease 86: 205-214.

Ronquist F, Teslenko M, van der Mark P, Ayres D, Darling A, et al. ( 2012) MrBayes 3.2: Efficient Bayesian phylogenetic inference and model choice across a large model space. Systematic Biology 61: 539-542.

Sakalidis ML, Hardy GESJ, Burgess TI (2011) Endophytes and potential pathogens of the baobab species Adansonia gregorii; a focus on the Botryosphaeriaceae. Fungal Ecology 4: 1-14.

Scott PM, Burgess TI, Barber PA, Shearer BL, Stukely MJC, et al. (2009) Phytophthora multivora sp. nov., a new species recovered from declining Eucalyptus, Banksia, Agonis and other plant species in Western Australia. Persoonia 22: 1-13.

Scott PM, Burgess TI, Hardy GESJ (2013) Globalization and Phytophthora. In: Phytophthora: a global perspective (Lamour K, ed.): 226-232. Wallingford: CAB International.

Schoebel CN, Stewart J, Grünwald NJ, Rigling D, Prospero S (2014) Population history and pathways of spread of the plant pathogen Phytophthora plurivora. Plos One 9 (1): e85368.
Swofford DL (2003) PAUP*: phylogenetic analysis using parsimony (*and other methods). Version 4. Sunderland, MA: Sinauer Associates.

Warfield CY, Hwang J, Benson DM (2008) Phytophthora blight and dieback in North Carolina nurseries during a 2003 survey. Plant Disease 92: 474-481.

Werres S, Marwitz R, Man in't Veld WA, de Cock A, Bonants PJM, et al. (2001) Phytophthora ramorum sp. nov., a new pathogen on Rhododendron and Viburnum. Mycological Research 105: 1155-1165.

White TJ, Bruns T, Lee S, Taylor J (1990) Amplification and direct sequencing of fungal ribosomal RNA genes for phylogenetics. In: PCR Protocols: a guide to methods and applications (Innes MA, Gelfand DH ,Sninsky JJ, White TJ, eds): 315-322. San Diego: Academic Press. 